NATIONAL BANK OF BELGIUM

Conference

150 th anniversary

WORKING PAPERS - RESEARCH SERIES

MONETARY UNION AND ECONOMIC GROWTH

John Vickers ${ }^{(*)}$

I am especially grateful to Andrew Bailey, Marion Kohler and Peter Westaway for their expert help in preparing this paper. I owe thanks also to Roger Clews, Phil Evans, Paul Fisher, Neal Hatch, Nigel Jenkinson, John Keyworth, Mervyn King, Don Kohn and John Townend for comments and suggestions on an earlier version. Responsibility for the contents of the paper rests however entirely with me.

*) Bank of England. 


\section{Editorial Director}

Jan Smets, Member of the Board of Directors of the National Bank of Belgium

\section{Statement of purpose:}

The purpose of these working papers is to promote the circulation of research results (Research Series) and analytical studies (Documents Series) made within the National Bank of Belgium or presented by outside economists in seminars, conferences and colloquia organised by the Bank. The aim is thereby to provide a platform for discussion. The opinions are strictly those of the authors and do not necessarily reflect the views of the National Bank of Belgium.

The Working Papers are available on the website of the Bank:

http://www.nbb.be

Individual copies are also available on request to:

NATIONAL BANK OF BELGIUM

Documentation Service

boulevard de Berlaimont 14

B - 1000 Brussels

Imprint: Responsibility according to the Belgian law: Jean Hilgers, Member of the Board of Directors, National Bank of Belgium. Copyright $\odot$ National Bank of Belgium

Reproduction for educational and non-commercial purposes is permitted provided that the source is acknowledged.

ISSN: $1375680 \mathrm{X}$ 


\title{
Editorial
}

On May 11-12, 2000 the National Bank of Belgium hosted a Conference on "How to promote economic growth in the euro area?". A number of papers presented at the conference is made available to a broader audience in the Working Papers series of the Bank. This volume contains the sixth of these papers. The other five papers were issued as Working Papers 5-9.

\begin{abstract}
This paper discusses possible links between monetary arrangements - in particular monetary union - and economic growth. It is stressed that growth depends ultimately on how the real economy works: there is no monetary magic that can conjure up growth. But monetary policy can contribute to conditions for sustainable growth by securing and maintaining price stability; monetary union might extend this. It might also deepen the single market. The elimination of nominal exchange rate movement among members of the union removes some sources of shock but also some ways of adjusting to shocks. This underlines the importance of other adjustment mechanism - especially supply-side flexibility, which is crucial for growth in any event.
\end{abstract}




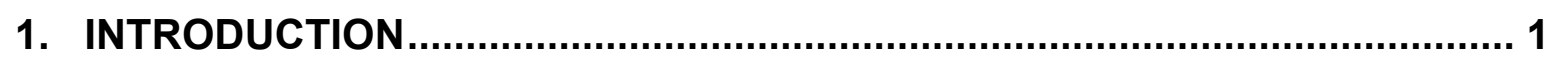

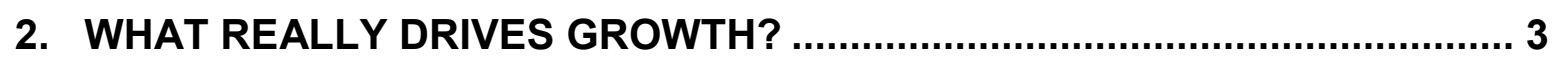

3. SO HOW CAN MONETARY ARRANGEMENTS MATTER FOR GROWTH?.. 6

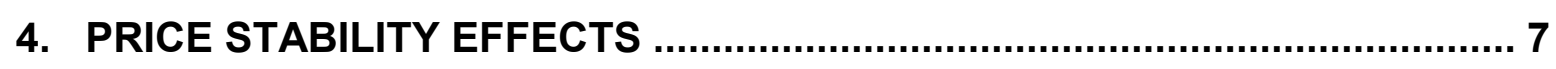

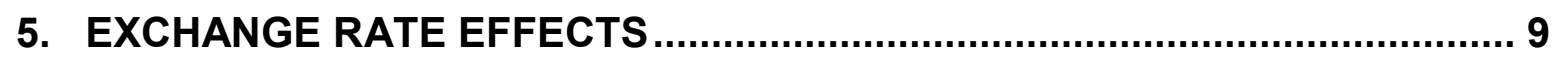

6. TRADE AND COMPETITION EFFECTS ................................................... 14

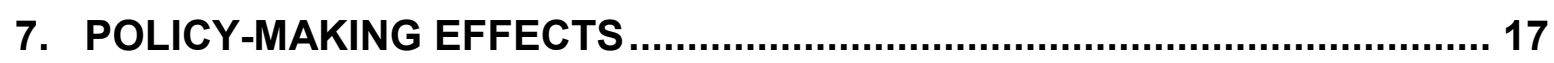

8. GROWTH AND INFLATION DIFFERENTIALS IN MONETARY UNION ........ 18

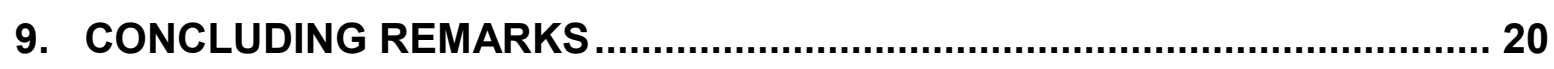




\section{INTRODUCTION}

Monetary union and economic growth was the subject for discussion at a dinner in London one evening in March 1925. The host was the Chancellor of the Exchequer, Winston Churchill. His guests were the Treasury grandees Bradbury and Niemeyer; the chairman of the Midland bank and former Chancellor McKenna; and an economist called Keynes. In case you were wondering, the Governor of the Bank of England was away.

The question was whether Britain should rejoin the Gold Standard, and the pre1914 parity of $\$ 4.86$. Oh to have been a fly on the wall! But we do have the next best thing - an account by a fly at the table, written years later by Churchill's private secretary James Grigg":

The symposium lasted till midnight or after. I thought at the time that the [progold] ayes had it. Keynes's thesis, which was supported in every particular by McKenna, was that the discrepancy between American and British prices was not 21/2 per cent as the exchanges indicated, but 10 per cent. If we went back to gold at the old parity we should therefore have to deflate domestic prices by something of that order. This meant unemployment and downward adjustments of wages and prolonged strikes in some of the heavy industries, at the end of which it would be found that these industries had undergone a permanent contraction ...

Bradbury made a great point of the fact that the Gold Standard was knave-proof. It could not be rigged for political or even more unworthy reasons. It would prevent our living in a fool's paradise of false prosperity, and would ensure our keeping on a competitive basis in our export business ... To the suggestion that we should return to gold but at a lower parity, Bradbury's answer was that we were so near the old parity that it was silly to create a shocked confidence and to endanger our international reputation for so small and so ephemeral an easement ...

One thing about this argument comes back to me with crystal clearness. Having listened to the gloomy prognostications of Keynes and McKenna, Winston turned to the latter and said: "But this isn't entirely an economic matter; it is a political decision ... You have been a politician; indeed you have been Chancellor of the Exchequer.

Quoted in Kynaston (1999, page 119). 
Given the situation as it is, what decision would you take?" McKenna's reply—and I am prepared to swear to the sense of it—was: "There is no escape; you have got to go back; but it will be hell".

Keynes later said that McKenna 'always lets one down in the end'. The decision to return to gold at the pre-war parity was made a few days later and announced in Churchill's Budget in April. The Bank of England strongly approved, though one director is reported ${ }^{2}$ to have resigned in protest-a Mr Vincent Vickers.

I have quoted this account at some length because it contains a number of themes that still resonate today, ranging from the importance of knave-proof monetary arrangements to the difficulties of equilibrium exchange rate analysis. But above all the question of the return to gold, and the events that followed, is a powerful illustration of how monetary arrangements can matter-for the real economy as well as for prices.

But how do they matter? Is it possible that a change in monetary arrangements might have a permanent effect on the real economy? In particular, does monetary union have any implications for the rate of growth of the real economy? These are the broad questions that I want to address today. My aim is limited to exploring the economic logic of some links between monetary union and growth, and does not extend to providing a comprehensive quantitative assessment, festooned with fan charts, policy recommendations, and so on. If you were hoping for the latter, then I have at least let you down right at the start.

By Moggridge (1972, page 95). The force of this protest is unclear, since records show that Mr Vickers had in fact ceased to be a director of the Bank in 1919. 


\section{WHAT REALLY DRIVES GROWTH?}

Although my task is to explore relationships between monetary union and growth, let us for a moment ignore monetary influences altogether. This is in fact what books on growth economics generally do. After all, just as inflation is a monetary phenomenon, so growth is a real phenomenon.

Among the most important real economic forces driving growth are:

- growth in hours worked

- growth in human capital

- growth in physical capital

- improved allocation of labour and capital across production activities

- better exploitation of economies of scale

- innovation and diffusion of improved technologies and methods.

Subtracting the first of these factors from output growth gives the rate of labour productivity growth - the growth of output per hour worked. The last three factors are elements of total factor productivity (TFP) growth—the growth in output not accounted for by growth in factor inputs.

Table 1 shows phases of per capita GDP growth for a number of European countries from 1820 to 1992 . It is immediately apparent from the table why the postwar period from 1950 to 1973 is called the Golden Age. Growth was 2-3\% higher than in previous or subsequent generations. The high output growth came largely from strong labour productivity growth—see Table 2 . 
Table 1

Phases of Per Capita Real GDP Growth

\begin{tabular}{lccccc}
\hline & $\mathbf{1 8 2 0 - 7 0}$ & $\begin{array}{c}\mathbf{1 8 7 0 -} \\
\mathbf{1 9 1 3}\end{array}$ & $\mathbf{1 9 1 3 - 5 0}$ & $\mathbf{1 9 5 0 - 7 3}$ & $\mathbf{1 9 7 3 - 9 2}$ \\
\hline West European Countries & & & & & \\
Austria & 0.7 & 1.5 & 0.2 & 4.9 & 2.2 \\
Belgium & 1.4 & 1.0 & 0.7 & 3.5 & 1.9 \\
Denmark & 0.9 & 1.6 & 1.6 & 3.1 & 1.6 \\
Finland & 0.8 & 1.4 & 1.9 & 4.3 & 1.6 \\
France & 0.8 & 1.5 & 1.1 & 4.0 & 1.7 \\
Germany & 1.1 & 1.6 & 0.3 & 5.0 & 2.1 \\
Italy & 0.6 & 1.3 & 0.8 & 5.0 & 2.4 \\
Netherlands & 1.1 & 0.9 & 1.1 & 3.4 & 1.4 \\
Norway & 0.5 & 1.3 & 2.1 & 3.2 & 2.9 \\
Sweden & 0.7 & 1.5 & 2.1 & 3.1 & 1.2 \\
Switzerland & n.a. & 1.5 & 2.1 & 3.1 & 0.8 \\
UK & 1.2 & 1.0 & 0.8 & 2.5 & 1.4 \\
& & & & & \\
\hline Arithmetic Average & 0.9 & 1.3 & 1.2 & 3.8 & 1.8 \\
Source: Maddison (1995, Table 3-2). & & & & \\
& & & & & \\
Table 2 & & & & \\
Rate of Growth of Labour Productivity (GDP per Hour Worked) & &
\end{tabular}

\begin{tabular}{lcccc}
\hline \hline & $\mathbf{1 8 7 0 - 1 9 1 3}$ & $\mathbf{1 9 1 3 - 5 0}$ & $\mathbf{1 9 5 0 - 7 3}$ & $\mathbf{1 9 7 3 - 9 2}$ \\
\hline Austria & 1.7 & 0.9 & 5.9 & 2.5 \\
Belgium & 1.2 & 1.4 & 4.5 & 2.9 \\
Denmark & 1.9 & 1.5 & 4.5 & 1.7 \\
Finland & 1.8 & 2.2 & 5.4 & 2.2 \\
France & 1.7 & 1.9 & 5.1 & 2.7 \\
Germany & 1.9 & 0.6 & 6.0 & 2.7 \\
Italy & 1.7 & 2.0 & 5.8 & 2.4 \\
Netherlands & 1.3 & 1.3 & 4.8 & 2.2 \\
Norway & 1.6 & 2.5 & 4.2 & 3.2 \\
Sweden & 1.8 & 2.8 & 4.1 & 1.3 \\
Switzerland & 1.5 & 2.7 & 3.3 & 1.7 \\
UK & 1.2 & 1.6 & 3.1 & 2.2 \\
& & & & \\
\hline \hline Arithmetic Average & 1.6 & 1.8 & 4.7 & 2.3
\end{tabular}

Source: Maddison (1995, Table 3-13)

Unlike in Japan over this period and other East Asian economies subsequently, where output growth was even greater, labour input growth in Western Europe was modest. The population of working age was not growing especially rapidly, and workers' annual average hours were declining, though human capital formation was probably substantial. Capital input growth made a large contribution to growth but most remarkable is the rate of TFP growth in the Golden Age - see Table 3. This was related to, among 
other things, the reallocation of labour - e.g. from agriculture to manufacturing industry (a process that had largely happened earlier in the UK) — and post-war reconstruction, catchup and convergence. Public policy fostered growth, for example by measures of international trade liberalisation-including the establishment of the European Community —and by sustaining macroeconomic stability.

Table 3

TFP growth in different periods (\% per year)

\begin{tabular}{lllll}
\hline \hline & $\mathbf{1 9 5 0 - 6 2}$ & $\mathbf{1 9 6 0 - 7 3}$ & $\mathbf{1 9 7 3 - 7 9}$ & $\mathbf{1 9 7 9 - 9 0}$ \\
\hline & & & & \\
Belgium & 1.9 & 3.9 & 1.5 & 1.4 \\
Denmark & 1.8 & 2.8 & 1.2 & 1.3 \\
France & 3.5 & 4.0 & 1.7 & 1.7 \\
West Germany & 4.5 & 2.7 & 1.8 & 0.8 \\
Italy & 4.3 & 4.6 & 2.2 & 1.3 \\
Netherlands & 2.6 & 3.1 & 1.5 & 0.9 \\
UK & 1.3 & 2.3 & 0.6 & 1.6 \\
\hline \hline
\end{tabular}

Source: Crafts and Toniolo (1996, Table 1.7)

Then came the notorious productivity growth slowdown, albeit a slowdown from an unusually speedy pace. As growth slowed, unemployment and macroeconomic volatility increased. The onset of the slowdown happened at the same time as the first OPEC oil price hike, and although post hike does not necessarily imply propter hike, the oil shock is an element of the explanation of the 1970s rise in European unemployment. What it and subsequent shocks cannot explain is the diversity of unemployment rates among countries in Europe. Institutional differences between labour markets are no doubt part of the explanation, but they seem unable to explain the rise in aggregate unemployment over time. This puzzle - how to explain European unemployment patterns both over time and across countries - is explored in a recent paper by Blanchard and Wolfers (2000). Their analysis suggests that the interaction between shocks and institutions is crucial. This general theme will recur in what follows. 


\section{SO HOW CAN MONETARY ARRANGEMENTS MATTER FOR GROWTH?}

Although growth is driven directly by real forces, monetary arrangements can have important indirect effects on growth through several channels. Of course monetary policy affects demand growth at short horizons by affecting short-term real interest rates, asset prices, and so on-as outlined in, for example, our Monetary Policy Committee's (1999) paper on the transmission mechanism of monetary policy.

But how can monetary arrangements influence the growth of supply capacity in the economy? This question has at least two aspects:

- long-run growth in 'steady-state'

- medium-run growth in transitional phases.

By the latter I mean not just phases of technological catch-up, or transitions from one steady state to another, but also the kind of protracted adjustment that Keynes spoke of at Churchill's dinner.

Bearing in mind both these aspects, the rest of my remarks will cover four links from monetary arrangements — and monetary union in particular — to supply-side growth:

- price stability effects

- exchange rate effects

- trade and competition effects

- policy-making effects.

I shall also comment on some monetary consequences of growth differentials within monetary union. 


\section{PRICE STABILITY EFFECTS}

The paper by Otmar Issing (2000) has already explored the relationships between price stability and growth at this conference, so I shall be brief. First, as a theoretical proposition, the steady-state inflation rate, which depends on monetary policy, will generally have some effects on steady-state output growth, and upon economic welfare more generally ${ }^{3}$. Inflation is a tax on real money balances, and taxes affect private behaviour and, via the fiscal arithmetic, have implications for government behavior. Inflation can also have significant negative effects especially on saving and capital accumulation—through interactions with the tax system ${ }^{4}$.

Second, in practice there appears to be no such thing as high steady-state inflation, for high inflation has generally been associated with volatile and uncertain inflation ${ }^{5}$. Inflation uncertainty has real costs — in terms of both risk and effort to avoid risk.

An example of these costs is housing finance, which in the UK, unlike elsewhere in Europe, has mostly taken the form of floating rate mortgage debt, though mortgages with rates fixed over some term have become more popular in recent years. When inflation is very uncertain, as it was in the UK for a generation from the late 1960s to the early 1990s, both fixed and floating rate debt have large risks. With fixed rate debt the risk is to the borrower's (and the lender's) real wealth. Higher-than-expected inflation arbitrarily shifts wealth from lender to borrower, and lower-than-expected inflation does the opposite. With floating rate debt the main risk is to household cash flows. If real wealth uncertainty dominates cash flow uncertainty, then floating rate debt will have relative attractions when inflation risk is high.

A credible commitment to price stability reduces both kinds of risk. More broadly it relieves financing decisions from the plague of large inflation uncertainty, and diminishes inflation risk premia in borrowing costs - to the benefit of households, businesses and government.

\footnotetext{
See, for example, Orphanides and Solow (1990), Woodford (1990) and Lucas (2000).

See, for example, Feldstein (1999) and Bakhshi, Haldane and Hatch (1997).

The Gold Standard era saw low average inflation but considerable volatility from year to year. So low inflation seems to
} be a necessary but not sufficient condition for stable inflation. 
Only when inflation is low and stable, and expected to remain so, are economic decisions free from such uncertainties and distortions.

Monetary union helps to contain the costs of high and uncertain inflation if it brings price stability to countries that would otherwise find that harder to secure and maintain. Exchange rate fixity to a sound currency or adopting such a currency provides a nominal anchor. It may have been a 'barbarous relic', but this is what the Gold Standard did in its time. The challenge in the modern era of managed money has been to create institutions - domestic or transnational- to achieve and maintain price stability. The architecture of European Monetary Union does this -it is certainly built to be knaveproof $^{6}$ - and the new monetary framework in the UK, which has just had its third birthday, is constructed with similar intent.

Apparently no paper nowadays on European monetary arrangements is complete without a reference to Alice in Wonderland. So let it be noted that the Knave of Hearts was an important agent of transparency (albeit at the behest of the Queen). For it was he who turned over and exposed the three gardeners (the 2, 5 and 7 of Spades) who, having planted the wrong rose trees, had thrown themselves face down as the Royal procession approached. 


\section{EXCHANGE RATE EFFECTS}

What is the relationship of monetary union to the issues of exchange rate volatility and the possibility of medium-term exchange rate misalignment?

The apparent break in the industrialised world's rate of productivity growth around the customary watershed of 1973 coincided not only with the first oil shock but also with the advent of an international monetary system in which the major currencies floated relative to one another. Previously, under the Bretton Woods system that prevailed from Keynes to Nixon, currencies were adjustably pegged to the dollar, which was in turn partly linked to gold. After the breakdown of the Bretton Woods system, exchange rates became more volatile. While the largest currencies floated, many European countries sought over time to limit exchange rate variability among their currencies in a series of steps that led to the creation of the euro last year.

Table 4, which is from a recent IMF paper on exchange rate regimes ${ }^{7}$, shows measures of the short-run variability of, and longer-run trends in, the nominal and real exchange rates of five industrialised countries and of what is now the euro area. In the Bretton Woods era nominal exchange rate variability was zero except from time to time when exchange rates were adjusted. The table shows that, by contrast, exchange rate variability has been substantial over the past twenty years. A quarterly standard deviation of $5 \%$, which is typical against the dollar, is considerable volatility. Nominal effective (i.e. trade-weighted) exchange rates have been somewhat less variable, but of the countries in the table, they have been much less so only for France and Germany, reflecting the success of efforts to achieve intra-European nominal exchange rate stability.

Mussa et al (2000, Table 2.1). 
Table 4

Selected Industrial Economies: Volatility of Bilateral and Effective Exchange Rates, 1980/II 1998/IV (in per cent)

\begin{tabular}{|c|c|c|c|}
\hline & $\begin{array}{l}\text { Bilateral versus } \\
\text { U.S. dollar }^{1}\end{array}$ & $\begin{array}{l}\text { Nominal Effective } \\
\text { Exchange Rate }^{2}\end{array}$ & $\begin{array}{c}\text { Real Effective } \\
\text { Exchange Rate }^{2}\end{array}$ \\
\hline \multicolumn{4}{|l|}{ Germany } \\
\hline Standard deviation of quarterly changes & 5.26 & 1.63 & 1.69 \\
\hline Trend quarterly appreciation ${ }^{3}$ & 0.72 & 0.47 & 0.13 \\
\hline \multicolumn{4}{|l|}{ Japan } \\
\hline Standard deviation of quarterly changes & 5.70 & 4.78 & 4.69 \\
\hline Trend quarterly appreciation ${ }^{3}$ & 1.28 & 1.98 & 0.70 \\
\hline \multicolumn{4}{|l|}{ France } \\
\hline Standard deviation of quarterly changes & 5.14 & 1.62 & 1.54 \\
\hline Trend quarterly appreciation ${ }^{3}$ & 0.30 & 0.19 & -0.03 \\
\hline \multicolumn{4}{|l|}{ United Kingdom } \\
\hline Standard deviation of quarterly changes & 5.23 & 3.62 & 3.85 \\
\hline Trend quarterly appreciation ${ }^{3}$ & -0.12 & -0.42 & -0.13 \\
\hline \multicolumn{4}{|l|}{ United States } \\
\hline Standard deviation of quarterly changes & $\ldots$ & 3.14 & 3.10 \\
\hline Trend quarterly appreciation ${ }^{3}$ & $\ldots$ & 1.39 & -0.30 \\
\hline \multicolumn{4}{|l|}{ Euro Area } \\
\hline Standard deviation of quarterly changes & 5.01 & 3.00 & 2.96 \\
\hline Trend quarterly appreciation ${ }^{3}$ & 0.35 & 0.67 & 0.21 \\
\hline
\end{tabular}

Source: Mussa et al (2000, Table 2.1)

1 All bilateral exchange rates are U.S. dollar per national currency.

2 Effective exchange rates are trade-weighted indices; the real effective exchange rate is based on the consumer price index.

3 Based on a regression of the natural logarithm of the level of the exchange rate on a time trend.

Monetary union obviously banishes nominal exchange rate variation among member countries. It does not-and should not-remove real exchange rate variation among them (see below). And of course nominal and real exchange rate variability remains relative to non-members of the union ${ }^{8}$. Mussa et al (2000, Table 2.2) present evidence that over the 1973-98 period, euro area countries had less exchange rate volatility than the euro area as a whole, but that short-run volatility for a 'synthetic' euro was broadly constant ${ }^{9}$.

On account of asymmetrical trade weights, moreover, the nominal effective exchange rates of member countries may behave differently. For example, from the start of 1999 to the beginning of May this year, the decline of $11 \%$ in Ireland's nominal effective exchange rate was twice as much as the $5 \frac{1}{2} \%$ decline experienced by Belgium —see

\footnotetext{
In the absence of very high and variable inflation, real exchange rate variability broadly matches nominal exchange rate variability for each country reflecting slow price adjustment in the short-run. The long-run real exchange rate trends for the countries in Table 4 are not flat but they are large only for Japan. Therefore long-run trends in nominal exchange rates mostly reflect inflation differentials.

$9 \quad$ This is because intra-area volatility has been limited by moves towards currency union, and this has dampened the exchange rate volatility of member countries. The exchange rate index for the euro area as a whole, however, has no weight on member country currencies. For example, it includes $\$$ and $£$ but not FF or DM.
} 
Chart 1. This reflects the fact that the majority of Ireland's trade is outside the euro area while most of Belgium's is within it. This example illustrates how a nominal exchange rate shift relative to a non-member currency can have asymmetrical effects among member countries $^{10}$.

\section{Chart 1}

Nominal Effective Exchange Rates

$$
01 / 01 / 99=100
$$

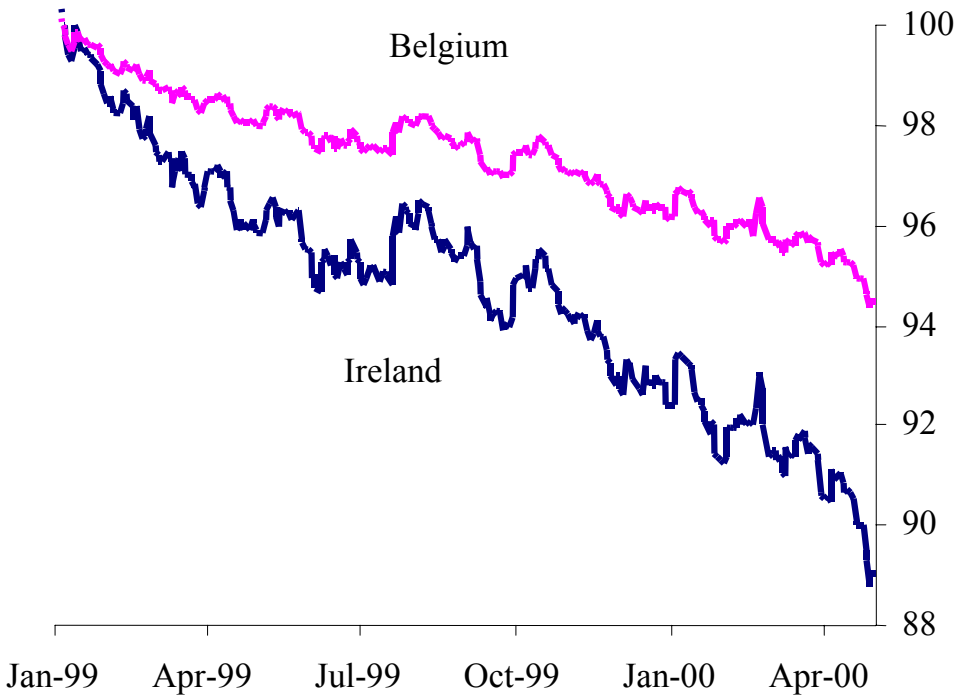

Exchange rate variability is an issue not just in the short term: there have also been large medium-term swings in exchange rates. In this regard Mussa et al point to the 1980-85 rise of the dollar and the 1990-95 rise of the yen, and their subsequent reversals. One might add the 1996-2000 decline in the euro and its predecessor currencies, and the corresponding rise in sterling. Such episodes raise the question of exchange rate misalignment, on which Mussa et al conclude judiciously:

Although exchange rate fluctuations are often equilibrating or reflect diverging cyclical positions or monetary policies, it seems likely that at least some large exchange rate movements for both advanced countries and emerging markets do not plausibly reflect economic fundamentals.

And of course the causes of the exchange rate shift in relation to the non-member currency could affect member countries differently. 
Exchange rate misalignment was of course Keynes's principal argument against Britain returning to Gold at the old parity in 1925. His concern was that the required process of deflation of domestic prices would cause real damage, and to supply capacity as well as to demand. In reaching this conclusion, Keynes did not simply assume nominal wage rigidities. He also highlighted how real wage inertia could hinder the necessary aggregate adjustment of money costs and prices $^{11}$ :

If every one was accepting a similar reduction at the same time, the cost of living would fall, so that the lower money wage would represent nearly the same real wage as before. But, in fact, there is no machinery for effecting a simultaneous reduction. Deliberately to raise the value of sterling money in England means, therefore, engaging in a struggle with each separate group in turn....

Two general points are illustrated by this argument. The first is that alternative processes of adjustment to misalignments and other economic disequilibria can have significantly different costs and therefore different economic consequences. Second, it is important if possible to avoid, or minimise the risk of, major misalignments, because adjustment processes can be difficult.

Subject to the key proviso of avoiding substantial misalignment at the outset, monetary union should on the whole help to prevent large misalignments among the real exchange rates of member countries. There is however the practical difficulty of knowing when, and if so how far, exchange rates are misaligned. Alas it is not a straightforward task to come up with definitive definitions or calculations of equilibrium exchange rates, and there is certainly no unanimity among those working in this field.

Of course, even if real exchange rates are well aligned at the outset, actual and equilibrium real exchange rates among member countries are likely to change over time and countries will in the normal course of events be subject to shocks. If equilibrium real exchange rates are required to move, adjustment must happen via differential inflation rates. In monetary union there is no alternative, since nominal exchange rate movement no longer exists. Moreover, domestic monetary policy is unavailable as an adjustment mechanism.

Keynes (1972, page 211). This essay was first published as a series of articles in the Evening Standard in July 1925. 
Other equilibrating mechanisms therefore become all the more important in monetary union. If they function poorly, the nominal exchange rate stability gains of monetary union may be offset, at least to some degree, by other kinds of macroeconomic instability. The effect of monetary union on growth therefore depends in part on how well other institutions and policies support economic flexibility. 


\section{TRADE AND COMPETITION EFFECTS}

The economic importance of EMU, and its potential implications for growth, goes far wider than the macroeconomic sphere. By extending the Single Market Project, EMU stimulates further the removal of inhibitions on the movement of goods, services, workers and (perhaps especially) capital. The common currency might promote competition also by enhancing the transparency and comparability of prices.

If monetary union does indeed add to the Single Market Project's promotion of trade and competition, how might that promote growth?

Most directly, foreign exchange transactions costs and hedging costs are saved. Arguably, the gains go much further. So claims Rose (2000), who presents estimates of the impact of monetary union on international trade over and above the elimination of exchange rate volatility. He concludes that 'two countries sharing the same currency trade three times as much as they would with different currencies'. It follows, says Rose, that currency unions such as EMU may lead to a large increase in international trade, and 'a big increase in trade will lead to substantial extra gains from trade for consumers inside the currency union'. Such gains could increase growth, at least for a transitional period, by improving resource allocation, specialisation, scale economies and other effects of competition on efficiency ${ }^{12}$.

Rose's striking claims can be questioned ${ }^{13}$. For example, fewer than $1 \%$ of the panel of bilateral trade relationships in his sample involved entities sharing a common currency, and many of those entities are quite small territories. And although Rose controlled for a number of underlying factors (e.g. common language) that might explain why trade and currency union tend to go together, it could still be that a common currency is a reflection of deeper institutional factors that favour trade, rather than a major causal factor. The question of how monetary union affects trade is nonetheless interesting and important, even if its answer is not yet fully resolved.

See, for example, Frankel and Romer (1999), and Proudman and Redding (1998).

13 And were questioned by Quah and other members of the Economic Policy panel-see the discussion at the end of Rose (2000). 
Turning to competition effects on growth more generally, three channels mentioned earlier were improved allocation of labour and capital across production activities; better exploitation of economies of scale; and innovation and diffusion of improved technologies and methods. Of course these channels also require factor mobility and free trade.

It is possible in endogenous growth theory to show how a shift in the level of competition could affect the steady-state rate of innovation and output growth ${ }^{14}$. Perhaps more directly, a step-up in competition could raise growth over a transitional period. For example, it might speed the catch-up of countries with lower levels of productivity. That would both enhance aggregate growth in the currency area and at the same time diminish regional disparities of income as all countries move towards the (ever-advancing) productivity frontier.

Krugman and others have shown, however, that such 'cohesion through integration' is not the only possibility as regards growth differentials within monetary union ${ }^{15}$. The argument is, first, that regional industrial clusters benefiting from economies of agglomeration are more likely to form in a more integrated economy. Indeed efficiencies from specialisation are among the potential sources of productivity gain from integration. Second, this specialisation makes regional economies more subject to asymmetric shocks, since regions are less diversified sectorally. Third, high factor mobility tends to magnify economic fluctuations - capital, for example, tending to flow to relatively booming sectors (and hence regions). As a result, the argument goes, integration need not reduce disparity in regional growth rates.

This question is pursued in a recent study by Braunerhjelm et al (2000). They analyse three broad types of outcome that could result from regional specialisation spurred by economic integration:

- a broad dispersion of activity with regional specialisation but not polarisation between regions

- strong geographical concentration accompanied by high labour mobility to faster growing regions away from others

\footnotetext{
14 See, for example, Aghion and Howitt (1998, chapter 7). The first endogenous growth models in the Schumpterian tradition tended to find a negative relationship between competition and growth, because the motivation for innovation was the gain of market power. This does not accord with empirical work, such as that of Nickell (1996), which has found a positive relationship between measures of competition and productivity growth. More recent theoretical work using richer concepts of competition has explored positive relationships between competition and growth.

15 See, for example, Krugman (1993) and Barrell and Pain (1998).
} 
- growing polarisation between prosperous regions with low unemployment and stagnant regions with high unemployment.

The authors argue that evidence on the mobility of capital relative to labour in Europe makes the concentration outcome unlikely, and that public policies have an important role to play in preventing polarisation. Their recommended policy recipe includes investment in skills, a pro-enterprise tax and regulatory framework, measures to promote wage flexibility in response to economic shocks, and avoidance of regional policies which 'try but fail to freeze existing patterns of economic activity'. These policies being supportive of growth in any event, the authors' central message is that 'growth and cohesion are not enemies; unless misguided policies determine otherwise, they are allies'. 


\section{POLICY-MAKING EFFECTS}

The competition and trade effects just discussed are examples of how monetary union can complement other public policies towards the real economy. There are other possible interactions between monetary union and public policy, and these too can have implications for economic growth.

First, at the macroeconomic level, the frameworks for fiscal and monetary policy are inter-related, since fiscal stability is a necessary complement to monetary stability. This is recognised in the architecture of EMU by the budget deficit and debt-to-GDP ratio criteria for participation in the common currency and by the Stability and Growth Pact. Over the medium term, these fiscal requirements of the commitment to monetary stability have contributed to processes of fiscal consolidation, and that in turn is likely to foster conditions for economic growth.

Second, fiscal policy is also part of the adjustment mechanism in response to asymmetric shocks within the common currency area. Of course neither the euro area, nor the European Union more generally, has a central budget on the scale of that of national governments. So international transfers via the automatic stabilisers of fiscal policy are in that sense limited. But those stabilisers still operate inter-regionally within member countries, and also inter-temporally insofar as the Stability and Growth Pact envisages cyclical variation in current fiscal positions ${ }^{16}$.

Third, one of the themes running through the earlier discussion is the role of economic flexibility in response to economic shocks. Such flexibility is important for growth and prosperity in any event. That importance is underlined by monetary union, because domestic monetary policy and intra-union nominal exchange rate movement are no longer available as adjustment mechanisms (though at the same time they disappear as potential sources of shocks). If for this reason monetary union enhances the impetus to supply-side reform, it will again be an ally of growth.

\footnotetext{
If Ricardian equivalence obtained, there would be no inter-temporal fiscal stabilisation of this kind via the tax system (though public expenditure could still be counter-cyclical), because government debt finance would be equivalent in effect to tax finance. In such a world there would however be little need for such stabilisation, because the private sector would achieve inter-temporal smoothing anyway in the face of shocks. (And stretching the theory yet further, the private sector could mutually insure in advance against shocks via financial markets, whose integration monetary union could well enhance.)
} 


\section{GROWTH AND INFLATION DIFFERENTIALS IN MONETARY UNION}

In any currency area the price stability objective of the central bank must concern the price level at the aggregate level. So the ECB's task is to maintain price stability for the euro area as a whole. This is quite consistent with inflation differentials across countries, which clearly exist at present-see Chart 2 . Indeed, the existence of different national inflation rates within a monetary union is to be expected as a normal state of affairs, partly for reasons relating to growth ${ }^{17}$.

\section{Chart 2}

\section{Euro-area Inflation Rates}

percentage change on a year earlier

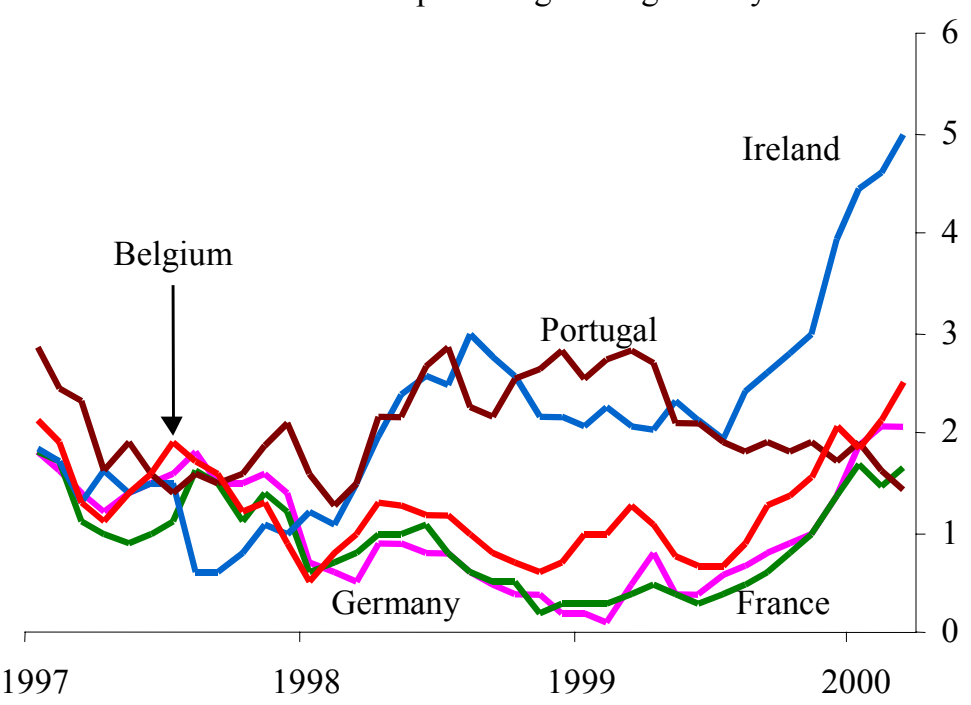

Inflation differentials would be absent only if there were no shifts in the price of one country's consumption basket relative to that of another country. This would be the case if prices for all goods and services were geographically uniform, and if, boringly, the typical consumer in each country had the same preferences among goods and services. Increasing competition, which monetary union might enhance, should promote geographical price convergence for tradable goods, but in the process that could itself give rise to inflation differentials.

Moreover, many goods and services are inherently non-tradable, and there would be little reason to expect non-tradables' inflation to be the same everywhere even if

For further discussion of the points below, see, for example, ECB (1999) and Obstfeld and Rogoff (1996, chapter 4). 
tradable goods prices were fully converged. Indeed, a country with relatively high productivity growth in tradables (relative to non-tradables) — which productivity catch-up might well imply - will tend to have higher-than-average inflation. This illustrates how growth differentials - which economic convergence requires - can give rise to inflation differentials.

This is not to say that all inflation differentials reflect equilibrium real exchange rate adjustments. Asymmetric cyclical positions, which might themselves come about partly in response to longer-term shifts in supply or demand conditions, may give rise to international differences in inflationary pressure. It is a familiar observation that, in a monetary union, policies other than monetary policy must address any adverse consequences of such asymmetries. The general point remains, however, that real exchange rates among members of monetary union naturally need to shift in the face of changing economic circumstances, and this can only happen through differential inflation rates. 


\section{CONCLUDING REMARKS}

There exists no monetary magic that can conjure up growth. Growth and prosperity depend ultimately on how well the real economy works. But monetary arrangements are part of the foundations for the real economy. The prime contribution that monetary policy can make to conditions for sustainable growth is to secure and maintain price stability. If monetary union has the effect of extending the domain of price stability, that should, other things being equal, be supportive of conditions for growth. If, moreover, monetary union has the effect of deepening the single market, that too should be positive for growth. The elimination of intra-union nominal exchange rate movement has effects of two kinds - some sources of shock are removed but so are some ways of adjusting to shocks. Monetary union therefore underlines the role of other adjustment mechanisms - in particular supply-side flexibility. That is of fundamental importance for growth in any event. 


\section{References}

Aghion, P and Howitt, P (1998), Endogenous Growth Theory, MIT Press, Cambridge MA.

Bakhshi, H, Haldane, A and Hatch, N (1997), 'Quantifying some benefits of price stability', Bank of England Quarterly Bulletin, Vol 37, pages 274-283.

Barrell, R and Pain, N (1998), 'Real exchange rates, agglomerations and irreversibilities: macroeconomic policy and FDI in EMU', Oxford Review of Economic Policy, Vol 14(3), pages 152-167.

Blanchard, $\mathrm{O}$ and Wolfers, $\mathrm{J}(2000)$, 'The role of shocks and institutions in the rise of European unemployment: the aggregate evidence', Economic Journal, Vol 110, pages C1-C33.

Braunerhjelm, P, Faini, R, Norman, V, Ruane, F and Seabright, P (2000), Integration and the Regions of Europe: How the Right Policies Can Prevent Polarization, CEPR, London.

Crafts, N and Toniolo, G (1996), 'Postwar growth: an overview', in Crafts, N and Toniolo, G, eds., Economic Growth in Europe Since 1945, CEPR and Cambridge University Press.

European Central Bank (1999), 'Inflation differentials in a monetary union', ECB Monthly Bulletin, October, pages 35-44.

Feldstein, M (1999), 'Capital income taxes and the benefits of price stability', in Feldstein, M, ed., The Costs and Benefits of Price Stability, University of Chicago Press.

Frankel, J and Romer D (1999), 'Does trade cause growth?', American Economic Review, Vol 89, pages 379-399.

Issing, O (2000), 'The contribution of monetary policy', paper presented at the conference to mark the $150^{\text {th }}$ anniversary of the National Bank of Belgium, Brussels.

Keynes, J M (1972), 'The economic consequences of Mr Churchill', in Essays in Persuasion, Vol IX of The Collected Writings of John Maynard Keynes, Macmillan, London.

Krugman, P (1993), 'Lessons of Massachusetts for EMU', in Torres, F and Giavazzi, F, eds., Adjustment and Growth in the European Monetary Union, Cambridge University Press.

Kynaston, D (1999), The City of London, Vol III, Chatto \& Windus, London.

Lucas, R (2000), 'Inflation and welfare', Econometrica, Vol 68, pages 247-274.

Maddison, A (1995), Monitoring the World Economy 1820-1992, OECD, Paris.

Moggridge, D (1972), British Monetary Policy 1924-1931, Cambridge University Press. 
Monetary Policy Committee (1999), The Transmission Mechanism of Monetary Policy, Bank of England, London.

Mussa, M, Masson, P, Swoboda A, Jadresic E, Mauro P and Berg, A (2000), 'Exchange rate regimes in an increasingly integrated world economy', IMF Occasional Paper No 193, Washington DC.

Nickell, S (1996), 'Competition and corporate performance', Journal of Political Economy, Vol 104, pages 724-746.

Obstfeld, M and Rogoff, K (1996), Foundations of International Macroeconomics, MIT Press, Cambridge MA.

Orphanides, A and Solow, R (1990), 'Money, inflation and growth', in Friedman, B and Hahn, F, eds., Handbook of Monetary Economics, North-Holland, Amsterdam.

Proudman, J and Redding, S, eds. (1998), Openness and Growth, Bank of England, London.

Rose, A (2000), 'One money, one market: the effects of common currencies on trade', Economic Policy, Vol 30, pages 9-45.

Woodford, M (1990), 'The optimum quantity of money', in Friedman, B and Hahn, F eds., Handbook of Monetary Economics, North-Holland, Amsterdam. 


\section{NATIONAL BANK OF BELGIUM - WORKING PAPERS SERIES}

1. "Model-based inflation forecasts and monetary policy rules" by M. Dombrecht and R. Wouters, Research Series, March 2000

2. "The use of robust estimators as measures of core inflation" by L. Aucremanne, Research Series, March 2000

3. "Performances économiques des Etats-Unis dans les années nonante" by A. Nyssens, P. Butzen, P. Bisciari, Document Series, March 2000.

4. "A model with explicit expectations for Belgium" by P. Jeanfils, Research Series, March 2000.

5. "Growth in an open economy: some recent developments" by S. Turnovsky, Research Series, May 2000

6. "Knowledge, technology and economic growth: an OECD perspective" by I. Visco, Research Series, May 2000

7. "Fiscal policy and growth in the context of European integration" by P. Masson, Research Series, May 2000

8. "Economic growth and the labor markets: europe's challenge " by C. Wyplosz, Research Series, May 2000

9. "The role of the exchange rate in economic growth" by R. MacDonald, Research Series, May 2000

10. "Monetary union and economic growth " by J. Vickers, Research Series, May 2000 